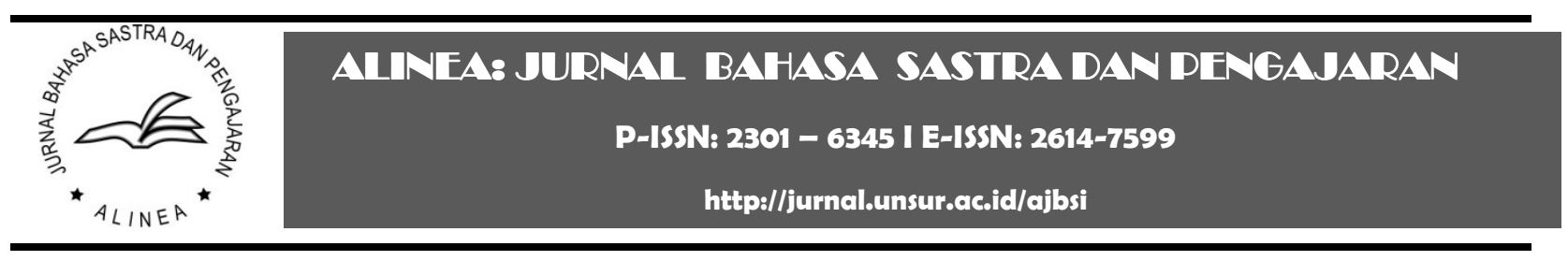

\title{
EFEKTIVITAS PEMBELAJARAN MEMBACA NOVEL DENGAN MENGGUNAKAN MODEL JIGSAW
}

\author{
Mira Annisa \\ Universitas Suryakancana, Cianjur
}

Riwayat artikel:

Dikirim: 16 Oktober 2018

Direvisi: 24 Oktober 2018

Diterima: 17 April 2019

Diterbitkan: 30 Oktober 2019

$\overline{\text { Katakunci: }}$

jigsaw

membaca

novel

religius

Alamat surat

nisa_ajjah15@yahoo.com

\begin{abstract}
Abstrak:
Artikel ini mendiskusi efektivitas pembelajaran membaca novel dengan menggunakan model Jigsaw di kelas XI IPA 3 SMA Al-Ittihad Cianjur. Metode yang digunakan dalam penelitian ini yaitu metode Penelitian Tindakan Kelas (PTK). Proses penelitian dimulai dari tahap perencanaan, pelaksanaan, observasi, dan refleksi. Teknik yang digunakan untuk pengumpulan data yaitu dengan instrumen observasi dan instrumen tes. Hasil penelitian penunjukkan bahwa penggunaan model Jigsaw dalam pembelajaran membaca novel dapat meningkatkan hasil pembelajaran. Kemampuan siswa dalam membaca novel dan menemukan nilai religius mengalami peningkatan. Aktivitas yang dilakukan siswa lebih aktif, berani, kritis dalam berargumen, baik menyanggah maupun menyetujui argumen serta mampu kerja sama dalam pembentukan kelompok.
\end{abstract}

\begin{abstract}
:
This article discusses the effectiveness of learning to read novels by using Jigsaw model in class XI IPA 3 at Al-Ittihad Cianjur High School. The method used in this study is the Classroom Action Research (CAR). The research process starts from the planning, implementation, observation, and reflection stage. The techniques used for data collection are observation and test instruments. The results of the study indicate that the use of the Jigsaw model in learning to read novels can improve learning outcomes. The ability of students to read novels and find religious values have increased. Activities undertaken by students are more active, brave, critical in arguing, both refuting or agreeing to arguments and able to work together in forming groups.
\end{abstract}

\section{PENDAHULUAN}

Dewasa ini faktor modernisasi kian hari kian berkembang. Hal ini tentu memberi dampak bagi kehidupan, baik berdampak positif maupun berdampak negatif. Salah satunya perkembangan internet. Dampak positifnya orang dapat dengan mudah mengakses segala informasi secara up to date, sedangkan dampak negatifnya orang cenderung ketergantungan menggunakan internet di kala menyelesaikan tugas-tugas yang dihadapkannya. Misalnya, tugas-tugas yang berkenaan dengan kegiatan menulis, baik itu tugas-tugasnya sebagai pelajar (bagi yang masih mengenyam pendidikan) ataupun sebagai pekerja (bagi yang sudah bekerja). Oleh karena itu, "Pembelajaran sastra di era
Revolusi Industri 4.0 perlu adaptif terhadap perkembangan media berbasis internet" (Triono et al.).

Meskipun demikian esensi pembelajaran sastra menurut Suminto Sayuti tidak berubah. "Tujuan itu pasti berorientasi pada literary knowledge dan literary appreciation. Orientasi itu dapat diturunkan menjadi knowing, doing, dan being sastra; apresiasi, ekspresi, dan produksi sastra; atau dapat dirumuskan dalam (istilah Jawa) nga-3: ngerti, nglakoni, dan ngrasakke sastra" (Sayuti).

Kurikulum mata pelajaran Bahasa dan Sastra Indonesia mencakup empat aspek keterampilan berbahasa, yaitu menyimak, membaca, berbicara, dan menulis. Pengajaran 
novel merupakan pengajaran yang tidak dapat dipisahkan dari pengajaran bahasa Indonesia. Dalam penyajiannya keempat aspek keterampilan berbahasa dan novel tersebut pelaksanaannya dilakukan secara terpadu dengan porsi seimbang.

Guru yang profesional adalah guru yang mampu mengetahui karakteristik dan perkembangan siswanya. Dalam pembelajaran novel, guru perlu mampu menyeimbangkan antara apresiasi dan teori novel, karena tujuan pengajaran novel untuk kepentingan pendidikan merupakan bagian dari tujuan pendidikan keseluruhannya, proses belajar dan mengajar novel merupakan bagian dari proses pendidikan. Kenyataan di lapangan menunjukkan bahwa guru bahasa dan sastra Indonesia berdasarkan kompetensi kesusastraan masih jauh dari kriteria guru bahasa dan sastra Indonesia ideal (Bahtiar).

Selain persoalan yang berkaitan dengan guru sastra, beberapa penelitian juga menjelaskan bahwa siswa kurang tertarik dalam pembelajaran sastra, sebagaimana juga dalam pembelajaran menulis umumnya siswa kurang memiliki minat yang memadai. (Novianti and Daud Pamungkas).

Pada saat ini, pengajaran novel hanya ditekankan pada kegiatan membina pengetahuan saja, sedangkan kegiatan yang bersifat apresiatif dan religius kurang diperhatikan. Hal ini membuktikan bahwa tujuan pengajaran novel yang sebenarnya belum tercapai secara optimal, atau kalau merujuk pada hasil penelitian Triono bahwa tujuan, fungsi, dan materi pengajaran sastra di dalam KTSP dan Kurikulum 2013 belum optimal merespon perkembangan era sastra digital (Triono et al.). Untuk itu, peran dan eksistensi guru Bahasa dan Sastra Indonesia sangat dibutuhkan untuk menangani pelajaran novel lebih serius.

Pengajaran sastra, khususnya novel merupakan bagian dari pengajaran Bahasa dan sastra Indonesia, tetapi bukan berarti pengajaran novel itu menjadi tidak penting.
Sesungguhnya pengajaran sastra, khususnya novel penting dalam dunia pendidikan, karena dapat membentuk sikap moral dan pribadi siswa ke arah yang positif dengan tujuan meningkatkan aspek religius siswa.

Menurut Romi Isnanda "Berbagai persoalan yang dapat ditanamkan pada generasi muda terkait pembelajaran sastra yang mengkaji kehidupan manusia, salah satunya dapat dijadikan sarana pembentukan karakter. Karakter merupakan cara berpikir dan berperilaku yang menjadi ciri khas setiap individu untuk hidup dan bekerja sama, baik dalam lingkup keluarga, masyarakat, bangsa, maupun negara (Isnanda).

Menurut Ahyadi aspek religius ialah suatu disposisi dinamis dari sistem mental yang terbentuk melalui pengalaman serta diolah dalam kepribadian untuk mengadakan tanggapan yang tepat, konsepsi pandangan hidup dan penyesuaian diri dan bertingkah laku (Samani).

Jalaludin Rakhmat mengatakan bahwa: "Agama dalam kehidupan individu berfungsi sebagai suatu sistem nilai yang memuat norma-norma tertentu. Secara umum normanorma tersebut menjadi kerangka acuan dalam bersikap dan bertingkah laku agar sejalan dengan keyakinan agama yang dianutnya. Sebagai sistem nilai agama memiliki arti yang khusus dalam kehidupan individu serta dipertahankan sebagai bentuk ciri khas (Rakhmat)

Berdasarkan hasil observasi dan wawancara dengan guru bahasa Indonesia kelas XI, diketahui bahwa selama ini metode pembelajaran yang digunakan adalah metode ceramah, karena metode ini dinilai lebih efektif untuk menyampaikan materi bahasa yang cukup banyak dengan waktu yang terbatas. Guru bahasa Indonesia kelas XI belum pernah menggunakan model Jigsaw. 
Model pembelajaran koorperatif tipe Jigsaw adalah sebuah model belajar kooperatif yang menitikberatkan pada kerja kelompok siswa dalam bentuk kelompok kecil. Seperti yang diungkapkan oleh Lie, bahwa "pembelajaran kooperatif model Jigsaw ini merupakan model belajar kooperatif dengan cara siswa belajar dalam kelompok kecil yang terdiri dari empat sampai enam orang secara heterogen dan siswa bekerja sama saling ketergantungan positif dan bertanggung jawab secara mandiri" (Rusman).

Hal itu dikarenakan selama ini siswa terbiasa hanya disuapi dalam menerima materi pelajaran, artinya guru masih mendominasi dalam pembelajaran di kelas. Sehingga pembelajaran bahasa Indonesia yang dilakukan lebih terpusat pada guru sementara siswa cenderung pasif. Saat pembelajaran berlangsung siswa tidak berani untuk menanyakan kesulitan dalam memahami materi maupun dalam mengerjakan soal yang diberikan guru. Inisiatif siswa kurang, hal tersebut nampak ketika guru memberi kesempatan kepada siswa untuk bertanya maupun berpendapat tetapi tidak dimanfaatkan dengan baik oleh siswa.

Pada umumnya siswa masih kurang menyukai pelajaran bahasa Indonesia, demikian juga dengan pembelajaran membaca novel sehingga siswa mengalami kesulitan untuk memahami pokok bahasan bahasa Indonesia yang dijelaskan oleh guru. Terlebih lagi jika mereka diberikan pertanyaan dengan sedikit variasi yang membutuhkan penalaran lebih. Hanya beberapa siswa yang mampu menjawab dengan benar, itupun siswa yang memang tergolong lebih pandai dari siswa yang lain di kelasnya. Selain itu, banyak juga siswa ketika guru menjelaskan suatu pokok bahasan yang baru, terkadang mereka lupa akan inti dari pokok bahasan yang telah dijelaskan pada pertemuan-pertemuan sebelumnya. Hal tersebut menunjukkan bahwa pemahaman konsep bahasa Indonesia siswa kelas XI masih rendah.
Sementara berdasarkan hasil tes awal yang peneliti lakukan terhadap siswa kelas XI, hanya 7 siswa yang mencapai KKM (Kriteria Ketuntasan Minimum) nilai KKM adalah 65 dengan nilai tertinggi adalah 73 , nilai terendah adalah 20 dan rata-rata nilai tes awal adalah 39,24. Melihat dari hasil pencapaian nilai siswa pada tes awal tersebut, maka semakin menunjukkan bahwa pemahaman membaca novel dalam konsep bahasa Indonesia siswa kurang dan perlu ditingkatkan.

Berdasarkan analisis situasi pembelajaran membaca novel di SMA Al-Ittihad Cianjur, berusaha untuk mencari penyelesaian dalam pembelajaran bahasa Indonesia dengan menerapkan model jigsaw sebagai upaya peningkatan pemahaman konsep membaca novel siswa, karena model jigsaw belum pernah dilaksanakan di kelas XI.

Artikel ini membicarakan kemampuan siswa dalam menemukan nilai religius dengan model jigsaw di kelas XI SMA Al-Ittihad Cianjur tahun ajar 2015-2016.

\section{METODE}

Metode yang digunakan dalam penelitian ini adalah Penelitian Tindakan Kelas (PTK). 'PTK adalah suatu bentuk penelitian yang bersifat rekreatif dengan melakukan tindakan-tindakan tertentu agar dapat memperbaiki dan atau meningkatkan praktikpraktik pembelajaran di kelas secara profesional' (Arikunto).

Lebih lanjut dijelaskan bahwa PTK adalah bentuk penelitian yang dilakukan secara kolaboratif dan partisipasif." Ini berarti dalam penelitiannya dapat dilakukan bersamasama dengan orang lain yang berminat sama dalam hal permasalahan penelitian, karena metode penelitian ini bersifat kolaboratif dan partisipasif. Sementara itu, menurut Kemmis dan Mc. Taggart "Penelitian tindakan merupakan penelitian yang bersiklus, yang 
terdiri atas rencana, aksi, observasi, dan refleksi yang dilakukan secara berulang" (Arikunto).

Beranjak dari beberapa pendapat di atas, metode yang digunakan dalam penelitian ini yaitu metode Penelitian Tindakan Kelas (PTK). Hal ini dilakukan untuk memperbaiki dan meningkatkan kemampuan siswa dalam efektivitas pembelajaran Karena penelitian ini bersifat perbaikan, tentu dalam pelaksanaan pembelajarannya tidak cukup dilakukan hanya satu kali pertemuan, tetapi perlu berulang dari siklus awal ke siklus berikutnya sehingga hasil belajar siswa dapat maksimal.

Subjek dalam penelitian ini adalah siswa Kelas XI IPA 3 SMA Al-Ittihad Cianjur dengan jumlah siswa 30 orang. Penelitian tindakan kelas ini dilaksanakan pada semester kedua dengan fokus penelitian pada pemahaman membaca novel dalam meningkatkan nilai religius pada pembelajaran bahasa Indonesia.

Instrumen yang digunakan pada penelitian ini adalah lembaran soal dan angket. Lembaran soal terdiri atas lima soal esai, sebagai acuan untuk mengukur pemahaman siswa dalam memahami teks negosiasi berdasarkan struktur dan tindakan dalam bernegosiasi. Sedangkan, angket diberikan kepada siswa sebagai bahan untuk menguji kualitas keefektifan pembelajaran dengan menggunakan pendekatan pembelajaran jigsaw.

\section{HASIL DAN PEMBAHASAN}

Kemampuan awal siswa dalam membaca novel dilanjutkan dengan hasil penelitian tindakan kelas yang berupa hasil tes dan nontes. Hasil tes meliputi siklus I dan siklus II. Hasil tes siklus I merupakan tes awal untuk mengetahui kondisi pembelajaran mengenai pemahaman siswa dalam memahami membaca novel dengan menggunakan model pembelajaran kooperatif tipe jigsaw. Hasil tes siklus II merupakan perbaikan dari siklus I tentang pemahaman siswa terhadap nilai-nilai religius setelah dilakukan pembelajaran dengan menggunakan pendekatan jigsaw.

Untuk mengetahui kemampuan awal siswa dalam memahami nilai religius dalam novel masih sangat rendah. Kemampuan awal tersebut diukur melalui interview dengan cara yang cukup sederhana seperti melontarkan pertanyaan-pertanyaan secara acak atau distribusi perwakilan siswa yang representatif di kelas yang menjadi sampel pada pra tindakan. Setelah melakukan interview, masih banyak siswa yang belum mengerti atau memahami nilai religius dalam novel.

Berdasarkan hasil analisis dan pengolahan data dari hasil penelitian yang telah dilakukan maka dapat dijelaskan beberapa hal yang berkaitan dengan tujuan pelaksaan pembelajaran yang dikembangkan, diantaranya sebagai berikut:

Pelaksanaan siklus I dilaksanakan dua kali pertemuan pembelajaran. Pertemuan pertama pada 12 Maret 2016 di kelas XI IPA 3 yang diikuti 30 siswa. Pelaksanaan pertemuan pertama dilaksanakan pada jam pelajaran $1-2$ yaitu pada pukul 07.20 - 8.40. Pertemuan kedua dilaksanakan pada 19 Maret 2016 pada jam pelajaran 1 - 2 yaitu pada pukul 07.20 8.40 .

Pada tahap ini peneliti atau guru, melakukan tindakan yang berupa intervensi terhadap pelaksanaan atau program yang menjadi tugas sehari-hari. Dalam setiap tindakan, peneliti merancang pembelajaran yang hendak diberikan kepada siswa, dan hal 
tersebut tersirat dalam setiap RPP yang dibuat. RPP tersebut diaplikasikan sesuai dengan pendekatan dan metode yang akan dipakai.

Pada tahap ini kegiatan yang dilakukan peneliti adalah melaksanakan tindakan kegiatan sesuai langkah yang direncanakan, yaitu melaksanakan pembelajaran membaca novel dan mencari nilai-nilai religius dalam novel dengan pendekatan jigsaw. Novel yang digunakan pada siklus I adalah novel 99 Cahaya di Langit Eropa karya Hanum Salsabiela Rais dan Rangga Almahendra (Salsabiela Rais and Almahendra). Pada siklus I kemampuan siswa baru mencapai rata-rata $56 \%$. Aktivitas tertinggi yaitu membuat kesimpulan sebesar $70 \%$, sedangkan aktivitas terendah yaitu mengajukan pertanyaan yakni hanya $40 \%$. Artinya, aktivitas belajar siswa pada siklus I masih rendah sehingga perlu ditingkatkan pada siklus berikutnya.

Hasil evaluasi secara kelompok mencapai rata-rata 66. Nilai tertinggi yang diperoleh kelompok yaitu 75, sedangkan nilai terendah yaitu 60. Batas ketuntasan belajar siswa adalah 65 sehingga dapat dikatakan bahwa hasil tes secara kelompok belum menunjukkan ketuntasan belajar. Hal ini berarti perlu ada perbaikan pembelajaran pada saat diskusi kelompok.

Pada siklus I dilaksanakan evaluasi pembelajaran tentang membaca novel kemudian mendiskusikan nilai-nilai religius. Evaluasi dilaksanakan secara individu dengan tujuan untuk mengetahui keberhasilan pembelajaran siklus I tentang pemahaman siswa pada bentuk komposisi membaca novel. Jumlah soal yang disajikan sebanyak 5 butir yang perlu diselesaikan dalam waktu 40 menit. Jenis tes yang dilakukan adalah tertulis dan bentuknya adalah uraian dengan tujuan untuk mengetahui pemahaman siswa pada nilai-nilai religius.

Nilai rata-rata yang dicapai siswa pada siklus I yaitu 62. Siswa yang sudah mencapai ketuntasan belajar yaitu 8 orang $(26,67 \%)$ dan yang belum mencapai ketuntasan jauh lebih banyak yakni 22 orang $(73,33 \%)$.

Dari hasil observasi, pembelajaran belum begitu lancar dan siswa tampak kurang aktif dalam belajar. Pada saat berdiskusi terjadi keributan. Selain itu, tampak malumalu dalam menyampaikan penjelasan kepada temannya.

Hasil catatan lapangan menunjukkan bahwa pada saat pindah kelompok siswa tampak mengalami kebingungan. Begitu juga pada saat menyampaikan penjelasan kepada anggota kelompoknya. Adapun hasil wawancara dengan siswa kebanyakan siswa mengatakan senang belajar dengan cara seperti ini, tetapi perlu penjelasan awal agar langkahlangkah yang perlu dilakukan dapat dipahami dengan baik.

Berdasarkan hasil analisis tes secara kelompok menunjukkan hasil yang belum optimal. Masih ada kelompok yang mengalami kesulitan dalam menyelesaikan soal-soal komposisi membaca novel sehingga belum mencapai ketuntasan belajar sebesar 65 . Begitu juga dengan hasil tes secara individu, siswa yang belum tuntas jauh lebih banyak daripada siswa yang sudah mencapai ketuntasan belajar sebesar 65 .

Berdasarkan hasil penelitian dan analisis dalam pembelajaran membaca novel pada siklus I terdapat permasalahan. Hasil yang diperoleh siswa belum mencapai tujuan yang diharapkan, maka perlu dilakukan siklus berikutnya. Beberapa hal yang perlu 
diperhatikan pada siklus II yaitu penjelasan langkah kerja sebelum kegiatan inti dimulai. Selain itu, perlu bimbingan pada saat siswa melakukan diskusi dengan kelompok dan pada saat memberikan penjelasan kepada anggota kelompok dalam mencari nilai-nilai religius.

Siklus II dalam penelitian ini juga dilaksanakan sebanyak dua kali pertemuan pembelajaran. Pertemuan pertama dilaksanakan pada hari Sabtu, tanggal 26 Maret 2016 pada jam pelajaran ke 1 - 2 yaitu pada pukul 07.20. - 08.40. Diikuti 30 siswa. Pertemuan kedua dilaksanakan pada hari Sabtu, tanggal 02 April 2016 pada jam pelajaran 1 - 2 yaitu pukul 07.20 - 08.40. diikuti 30 siswa. Pembelajaran pada Siklus II yaitu dengan menyajikan materi membaca novel Surga yang Tak Dirindukan karya Asma Nadia, kemudian mencari nilai-nilai religius yang terdapat pada novel tersebut dengan menggunakan model kooperatif tipe jigsaw. Aktivitas belajar siswa pada siklus II mencapai rata-rata $72 \%$. Aktivitas tertinggi yaitu memperhatikan penjelasan guru, menjawab pertanyaan, berani tampil ke depan, dan membuat kesimpulan, masing-masing $80 \%$, sedangkan aktivitas terendah yaitu diskusi kelompok dan mengajukan pertanyaan yakni hanya $60 \%$. Artinya aktivitas belajar siswa pada siklus II pada umumnya sudah cukup.

Hasil evaluasi secara kelompok mencapai rata-rata 74 . Nilai tertinggi yang diperoleh kelompok yaitu 80, sedangkan nilai terendah yaitu 70. Batas ketuntasan belajar siswa adalah 65 sehingga dapat dikatakan bahwa hasil tes secara kelompok sudah menunjukkan ketuntasan belajar.

Pada siklus II dilaksanakan evaluasi pembelajaran tentang bentuk membaca novel. Evaluasi dilaksanakan sebagaimana siklus I yakni secara individu dengan tujuan untuk mengetahui keberhasilan pembelajaran siklus II tentang pemahaman siswa pada upaya menemukan nilai-nilai religius. Jumlah soal yang disajikan sebanyak 5 butir yang perlu diselesaikan dalam waktu 40 menit. Jenis tes yang dilakukan adalah tertulis dan bentuknya adalah uraian.

Nilai rata-rata yang dicapai siswa pada siklus II yaitu 69,67. Siswa yang sudah mencapai ketuntasan belajar yaitu 19 orang $(63,33 \%)$ dan yang belum mencapai ketuntasan jauh lebih banyak yakni 11 orang $(36,67 \%)$. Hal ini terlihat jelas pada Grafik 4.4 bahwa batang ketuntasan belajar untuk kriteria tuntas lebih tinggi daripada batang tidak tuntas, sehingga kemampuan individu dalam memahami materi pelajaran membaca novel sudah cukup walaupun meskipun ada yang belum tuntas.

Hasil observasi kegiatan belajar secara kelompok ada peningkatan dari siklus I. Kerja sama antara anggota kelompok kondusif, tetapi dalam pelaporan LKS ada sedikit keributan ingin membacakan hasilnya. Hasil catatan lapangan dan wawancara, siswa tidak mengalami hambatan yang berarti. Hal ini didukung oleh hasil LKS bahwa tidak mengalami kesulitan dalam mengerjakan soalsoal yang disajikan. Berdasarkan hasil analisis dapat disimpulkan bahwa pembelajaran berjalan lancar. Hasil evaluasi cukup baik hal ini berarti kemampuan individu dalam memahami nilai-nilai religius ada peningkatan dari siklus I.

Aktivitas belajar sudah mengalami peningkatan terlihat dari hasil tes secara invividu yang sudah tuntas. Beberapa hal tersebut terlihat pada siklus II yaitu memberikan penjelasan mengenai pentingnya kerja sama dan saling menghargai pendapat teman. Selain itu, pemberian bimbingan 
kepada siswa pada saat menyampaikan hasil diskusi agar pembelajaran berjalan lancar.

Untuk mengetahui respon siswa terhadap pelaksanaan pembelajaran membaca novel dengan menggunakan model kooperatif tipe jigsaw selanjutnya siswa diberikan angket tertutup. Pemberian angket dilakukan satu kali yakni setelah dua siklus selesai.

\section{PENUTUP}

Berdasarkan hasil penelitian dan analisis terhadap pembelajaran membaca novel dalam meningkatkan nilai religius dengan menggunakan model jigsaw siswa kelas XI SMA Al-Ittihad Cianjur, maka simpulan yang didapat adalah sebagai berikut.

Pelaksanaan pembelajaran membaca novel dalam meningkatkan nilai religius dengan pendekatan pembelajaran jigsaw pada siswa kelas XI SMA Al-Ittihad mengalami perbaikan pembelajaran, yaitu dari aktivitas guru dan siswa yang masih mengalami hambatan menjadi tidak mengalami hambatan.

Hasil kemampuan siswa dalam membaca novel dan menemukan nilai religius dalam novel setiap siklusnya mengalami peningkatan. Dengan menggunakan model koopratif tipe jigsaw aktivitas yang dilakukan siswa lebih aktif, berani, kritis dalam berargumen, baik menyanggah maupun menyetujui argumen serta mampu kerja sama dalam pembentukan kelompok.

Beberapa saran yaang ingin dikemukakan adalah sebagai berikut.Pertama, guru hendaknya memiliki kreatifitas dalam memberikan pembelajaran kepada siswa misalnya dengan menggunakan pendekatan pembelajaran yang bervariasi agar siswa tidak bosan dalam pembelajaran dan akan menyukai pembelajaran yang diajarkan.

Kedua, pendekatan pembelajaran jigsaw merupakan salah satu alternatif yang dapat digunakan oleh guru dalam melaksanakan pembelajaran bahasa Indonesia khususnya teks negosiasi agar pembelajaran dan materi yang disajikan terasa lebih menyenangkan dan lebih bermakna sehingga siswa tidak merasa jenuh.

Sebelum melaksanakan pembelajaran dengan menggunakan pendekatan pembelajaran berbasis masalah perangkat pembelajaran seperti RPP dan soal tes perlu dipersiapkan lebih baik. Dalam melaksanakan pembelajaran dengan menggunakan pendekatan pembelajaran berbasis masalah, guru perlu dapat mendistribusikan waktu sebaikbaiknya.

Terakhir, perlu penelitian lebih lanjut mengenai penerapan pendekatan pembelajaran yang sesuai dengan mata pelajaran maupun materi pelajaran dimana pendekatan tersebut bisa menghasilkan prestasi akademik yang maksimal.

\section{DAFTAR PUSTAKA}

Arikunto, Suharsimi. Prosedur Penelitian Suatu Pendekatan Praktis. Rineka Cipta, 2010. 
Bahtiar, Ahmad. "Kompetensi Kesusastraan Guru Bahasa Dan Sastra Indonesia Di Wilayah Tanggerang Selatan." Journal Indonesian Language Education and Literature, vol. 2, no. 1, 2017, pp. 203-18.

Isnanda, Romi. "Peran Pengajaran Sastra dan Budaya dalam Pembentukan Karater Siswa Sekolah Dasar." Gramatika STKIP PGRI Sumatera Barat, vol. 1, no. 2, 2015, pp. 174-82, doi:10.22202/jg.2015.v1i2.1237.

Novianti, Hani, and Daud Pamungkas. "Using Transformation Technique to Improve Writing Skill of Short Story.” Alinea: Jurnal Bahasa, Sastra, dan Pengajaran, vol. 1, no. 3, Oct. 2018, p. 177, doi:10.35194/alinea.v1i3.368.

Rakhmat, Jalaludin. Jalan Rakhmat: Mengetuk Pintu Tuhan. PT Gramedia Pustaka Utama, 2013.

Rusman. Model-Model Pembelajaran. Raja Grafindo Persada, 2008.

Salsabiela Rais, Hanum, and Rangga Almahendra. 99 Cahaya di Langit Eropa. Gramedia Pustaka Utama, 2011.

Samani, Hariyanto. Konsep dan Model Pendidikan Karakter. PT Remaja Rosdakarya Ofset, 2011.

Sayuti, Suminto A. "Pembelajaran Sastra di Sekolah dan Kurikulum 2013." Litera, vol. 1, no. 2, 2015, pp. 112-22.

Triono, Eko, et al. "Pengajaran Sastra dalam KTSP dan K13 Jenjang SMA di Era Digital." Jurnal Gramatika, vol. 5, no. 1, 2019, pp. 102-11, doi:10.22202/JG.2019.V5i1.3209. 